\title{
Ten theses concerning social conflict in Latin America
}

\author{
Fernando Calderón
}

ABSTRACT

Conflict in the countries of Latin America presents common features: platforms of exclusion and chronic inequalities that are under challenge from citizens; complex struggles relating these inequalities with their number and intensity; a combination of social protests that are manifested both at the national level and at the general cultural level; practical rationalities in the tensions arising from social reproduction ${ }^{1}$ that coexist with demands for greater institutional efficiency and effectiveness and with systemic cultural conflicts. Other common factors are States that are omnipresent in all spheres of conflict but have only a limited ability to process them, and societies with fragmented conflicts; new public spaces where tensions are represented in a contradictory way, and conflicts that have been moving on to information and communication networks, with multiplier effects in the new environments where power is increasingly exercised. There is increased social complexity related to political systems and States with limited management capabilities. The situations and scenarios in prospect are diverse and options remain open.

KEYWORDS

JEL CLASSIFICATION

AUTHOR
Social conflict, social issues, cultural issues, social conditions, income distribution, social integration, equality, government decentralization, mass media, Latin America

O15, O54, Y90

\footnotetext{
1 This means that actors are driven mainly by a logic of concrete results that help to meet their social reproduction needs. Ideological narratives are circumstantial to the political situations experienced.
} 


\section{I \\ The context}

The world today is at a critical juncture, since a number of different crises are coming to a head at the same time, as are transformations and choices of a financial, multicultural, environmental and political nature. What is unprecedented is the way changes with multiple characteristics are now manifesting themselves in full force.

Certain features of globalization are undergoing a process of transcendental change, and this is coinciding with a far-reaching recomposition of economic power and the sources of the planet's economic growth. A new multilateralism is taking root. The new emerging economies are adopting "heterodox" models of capitalism or the market economy, associated with political orientations whose ideological discourses are divergent: practical reformism, popular nationalism, ${ }^{2}$ "neo-developmentalist indigenism" and conservative modernization (Calderón, 2008).

In Latin America, the economy has grown, poverty has been reduced and progress has been made with some distributive effects (ECLAC, 2010a; UNDP, 2009). The region has displayed remarkable political and managerial capabilities in dealing with the global crisis. In addition, growth projections there are quite favourable (Aranibar, Vázquez and Garzón, 2011).

However, productive transformation and the switch to a knowledge economy do not seem to be occurring as dynamically as is required if progress is to be made with the region's grave problems of poverty and inequality. Social inclusion and innovation are an equation that has yet to be solved. Similarly, a number of indicators of political legitimacy have improved; nonetheless, too little progress has been made towards a democracy of citizens (UNDP, 2004).

The problem is to know how to progress in this direction. What political capabilities are required? How can growth, redistribution and environmental sustainability be skilfully combined? How can the

\footnotetext{
$\square$ The author is grateful for the assistance of Lorenza Fontana, María Isabel Nava and Huascar Pacheco in the preparation of this document, to PAPEP-United Nations Development Programme (UNDP) and to the UNIR Foundation in Bolivia for allowing the use of findings from the report Los conflictos sociales en América Latina, which was coordinated by the author.

2 The people are identified with the nation and the State. See Calderón (2008).
}

political cycle the region is going through be associated with a cycle of transformations in its economic and production structures? How can cultural pluralism and institutions continue to be constructed in a manner suited to innovative economic change? A central issue in all these processes is social conflict and the ways this can be dealt with from a perspective that treats democracy as institutionalized conflict. This is the area the present study covers. The theses that will now be presented need to be viewed from a threefold perspective: historically, conceptually and as part of the process of global change.

In most of the region's countries, the common, central and historical feature of the contemporary conflict dynamic is the early appearance of the State as a social actor, something that not only reflects these societies' tendency towards social and political conflict but that has actively shaped the systems of economic interests and political actors which define the dynamic of conflict.

In the first cycle of populism experienced by the region, conflicts turned upon and were directed towards the formation of an autonomous nation-State, industrialization and the development of an inclusive modernization process underpinned by a solid culture of popular nationalism (Touraine, 1988). ${ }^{3}$

Under the dictatorships, the conflicts which social actors generated were in essence purely defensive actions, since authoritarian regimes "resolved" any manifestation of conflict by repression. Struggles and demands for human rights and political democratization developed with increasing force in this context (Ansaldi, 1986).

Democratization gave rise to new fields of conflict and to the revitalization of social movements or the emergence of new ones, or both. All this is analysed in the series of national studies entitled Los movimientos sociales ante la crisis (Calderón, 1986). In this study, a first field of conflict identified was the defence of workers' status. A second field were demands for urban quality of life, collective consumption and decentralization. A third field were rural conflicts over land, the market and ethnic recognition. Human rights and the quest for

\footnotetext{
${ }^{3}$ A culture of popular nationalism is one that seeks political hegemony, centralization of development and democracy in the State, mass mobilization and charismatic leadership.
} 
equitable gender relationships were another significant field of conflict in this period.

Following structural reforms, conflict turned on the defence of living conditions and the discontent created by the reification of the market. In the late 1990s, in what was a historic turning point in terms of both democracy and development, a new type of conflict emerged, one that was more socially complex and multifaceted, with both conflicts and actors proliferating. Most prominent in this context were conflicts turning on multiculturalism and positions relating to new forms of quality of life, citizenship and dignity (PAPEP-UNDP, 2011).

Conceptually, the region's conflicts can be said to link demands for real freedom and cultural freedom. By the former is meant a set of demands whose objective is to meet the needs of a decent life so that people can then go on to build capacities and choose the type of life they wish to lead, in accordance with their own values and aspirations. By the second is meant recognition of the identities and rights of individuals and cultural communities, in connection with the right to adopt and change identities (Sen, 1999; UNDP, 2004).

In the conceptual approach of this article, constructivist policy is taken to be the best way of processing conflicts. ${ }^{4}$ Political constructivism comes to terms with socioeconomic realities and power gambits in the effort to strengthen democracy, and sets out from the recognition of a sociocultural plurality out of which a common order has to be created, without losing sight of the fact that this order is the outcome of a process of conflict. Conflict is not synonymous with war; rather, the institutionalized conflict inherent in diversity and interculturality is the precondition for democracy and peace. According to this approach, politics and social actors are being constantly made and remade in conflict that is sustained by unequal power relationships which are also real and historical. Consequently, actors are shaped in politics, where everyone is subject to power relationships. This text synthesizes a normative view of politics as value-oriented politics. As Gianni Vattimo would have it, we do not agree when we have the truth; rather, we find the truth when we agree (Vattimo, 2006).

\footnotetext{
${ }^{4}$ The basis for political constructivism is the political ability of actors to create an order with an integral role for conflict based on interaction and mutual recognition between those who are different or opposed, something that entails an appreciation of the freedom and identity of the other. Constructivist policy can be understood as the art of the best possible. Policymaking entails the exchange of reciprocal recognitions (PAPEP-UNDP, 2011, chapter 1). Methodologically, to explain this type of action it is essential to determine the structural and institutional bases on which action rests and the effects of the socialization with which actors are associated (Boudon and Bourricaud, 1982, p. 308).
}

This paper does not argue for or against any particular type of society. What it argues for, primarily, is an institutionalized political way of accommodating differences so that shared goals can be constructed without denying the existence either of power or of conflict and disagreement in all sorts of areas. Here, politics becomes not an instrument of negotiation but an exercise in understanding the memory and freedom of the other.

From this perspective, the argument is that a society which produces conflict and change that is constructively processed through institutions will be more fertile in democracy and development, whereas if the society produces conflicts and its institutions are poor at processing these, the results in terms of democracy and development will be problematic, as they will be if the society is poor at producing conflict and change and its institutions are strong but are unable to process conflicts democratically. In situations where society, the State and institutions are all weak, as will be seen later on, informal systems of intermediation and oversight are what will prevail in the reproduction of the social order. For Latin America, the classic thinking of Marcel Mauss is still important.

In summary, how do conflicts affect democracy and development opportunities? This is exactly the question the present article sets out to answer.

Methodologically, the conflicts identified and interpreted in this study have been taken from the narratives developed by 54 periodicals in 17 countries of the region over a year. These publications represent different ideological positions, have substantial markets for information and often form part of complex global and local networks relying on the use and development of the new information and communication technologies (ICTS). This being so, it is very important to emphasize that the empirical basis for this study are the conflicts reported on by the periodicals selected. Although these and other media helped to shape public opinion about these events, a larger number of conflicts went unreported. This is obviously a serious limitation for studies of this kind, which in any event often confuse reporting with reality. However, consistency tests were carried out using other statistical sources covering national and sectoral cases, and similar qualitative trends were found. Nonetheless, it must be realized that the information is inadequate. What were mainly studied here were conflicts in the public communication space, on the basis of the written press.

Quantitatively, Latin America is confirmed as a region with a substantial level of conflict. Yet the study 
was conducted in a period when the continent was emerging from the global crisis and there was relative sociopolitical stability. It was a time when the "box" where intense radicalism and widespread conflict appear was empty. There were no serious crises of governance in the region, other than the coup in Honduras. The analysis detected 2,318 conflicts and 4,724 conflict episodes between October 2009 and September 2010. Broadly speaking, the countries with the largest number of conflicts were Argentina, Peru and the Plurinational State of Bolivia, with a total of over 200. The countries with the fewest conflicts in the region were Chile, Costa Rica and El Salvador, averaging 58. The countries where conflicts were most radical were the Bolivarian Republic of Venezuela, Chile and the Dominican Republic, while they were least radical in Costa Rica, Panama and Peru. Figure 1 shows the degree of radicalization; and this is where Pandora's box opens.

FIGURE 1

Radicalization pyramid

\section{Chaos}

\section{Violent clashes}

Seizure of facilities/institutions/places. . . . . . . . . . . . . . . . $6.1 \%$

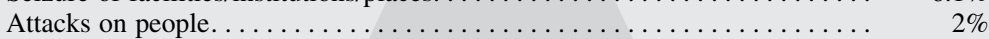

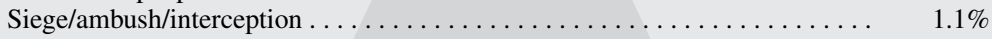

Armed uprising

\section{Confrontation}

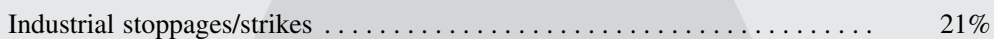

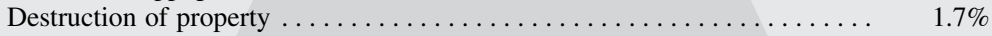

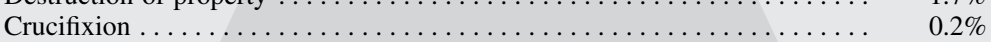

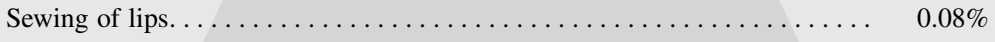

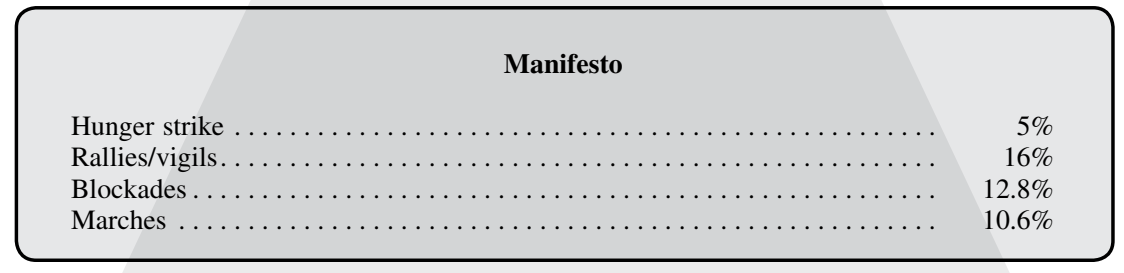

Pre-conflict

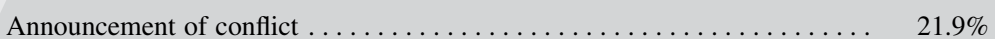

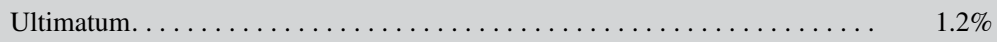

Source: Political Analysis and Prospective Scenarios Project-United Nations Development Programme (PAPEP-UNDP), Los conflictos sociales en América Latina, La Paz, 2011. 


\section{II}

\section{The theses}

The theses that will now be presented highlight the most frequent characteristics, common features and shared challenges facing the different Latin American societies.

\section{Thesis 1}

The characteristics of Latin America's complex inequality are bound up not only with significant levels of social differentiation and high levels of wealth and income concentration, but also citizens' discontent with and questioning of these levels of inequality. This is why inequality underlies most of the social protests and conflicts in the region.

Latin America has been enjoying a favourable economic environment, buttressed by a sound macroeconomy, high growth and a degree of redistribution through social policies; inequality remains a structural problem in the region, however. The UNDP Regional Human Development Report for Latin America and the Caribbean 2010 mentions three characteristic features of inequality in Latin America and the Caribbean: it is high, persistent, and reproduced in a context of low socioeconomic mobility. The report also emphasizes that the region's countries are among the world's most unequal in household per capita income terms: 10 of the world's 15 most unequal countries are Latin American. Thus, the Gini income coefficient for Latin America and the Caribbean is " $65 \%$ higher than in high-income countries, $36 \%$ higher than the income inequality observed in East Asian countries, and 18\% higher than the level reported for sub-Saharan Africa" (UNDP, 2010, p. 37).

Figure 2 shows the high levels of concentration in the region's income distribution, with the richest $20 \%$ of the population receiving $56.81 \%$ of all income and the poorest $20 \%$ just $3.4 \%$. According to Forbes magazine, the richest in Latin America received US $\$ 332$ billion between them, 17 times as much as the gross domestic product (GDP) of the Plurinational State of Bolivia and 19 times as much as the GDP of Paraguay (Forbes, 2011).

Citizens perceive these levels of inequality as unfair and there is a standing demand for change, which explains the strength of social conflicts even in situations where major progress has been made in reducing the poverty Latin America has suffered from (see
FIGURE 2

\section{Income distribution}

(Income quintiles and percentages)

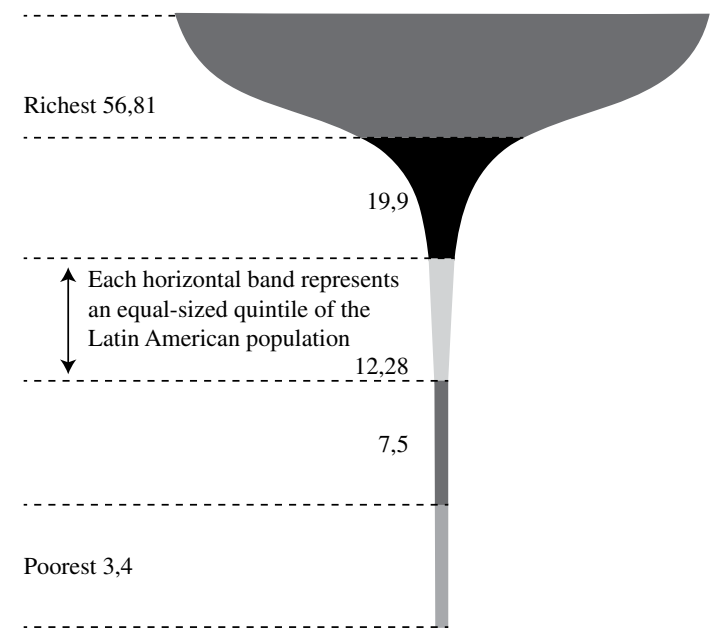

$\begin{array}{lr}\text { Latin American population } & \text { Income } \\ \text { Richest 20\% } & 56,8 \% \\ \text { Second 20\% } & 19,9 \% \\ \text { Third 20\% } & 12,2 \% \\ \text { Fourth 20\% } & 7,5 \% \\ \text { Poorest 20\% } & 3,4 \%\end{array}$

Source: prepared by the author on the basis of data from the Economic Commission for Latin America and the Caribbean (ECLAC), "CEPAlstat. Latin America and The Caribbean Statistics", 2009.

figure 3). ${ }^{5}$ According to data from Informe Latinobarómetro $2010,79 \%$ of Latin Americans consider that income is distributed unfairly.

\section{Thesis 2}

The public media space is increasingly where social conflicts are given expression and narratives about them constructed. This is bound up with the massive expansion and proliferation of the new ICTs. Actors in conflicts need the communications media and these need conflicts in a media logic of conflict and power.

\footnotetext{
${ }^{5}$ According to the Social Panorama of Latin America, the number of poor people fell by $5 \%$ in 2010 , in a resumption of the regional poverty reduction trend that began in 2003 (ECLAC, 2010c).
} 
FIGURE 3

\section{Perceptions of wealth distribution in Latin America, 2010}

(Percentages)

Proportions answering "Very fair" and "Fair" to the question: "How fair do you think the distribution of income is in (country)?"

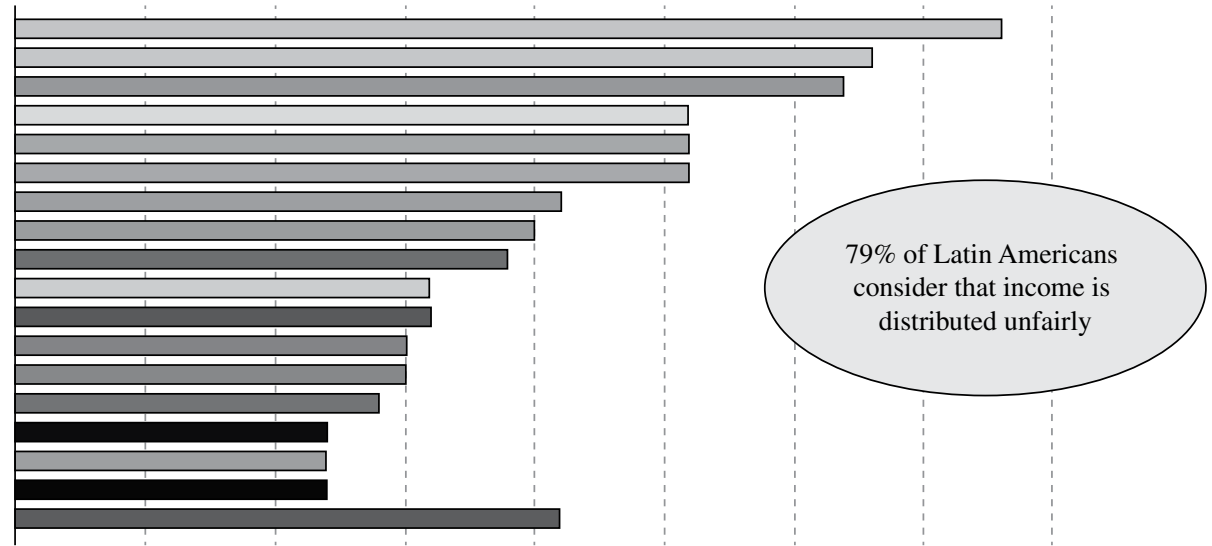

$\square$ Series 1, Venezuela (Bol. Rep. of), 38
$\square$ Series 1, Ecuador, 33
$\square$ Series 1, Panama, 32
$\square$ Series 1, Bolivia (Plur. State of), 26
$\square$ Series 1, Uruguay, 26
$\square$ Series 1, Costa Rica, 26

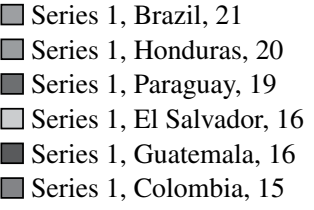

Series 1, Mexico, 15

Series 1, Peru, 14

Series 1, Chile, 12

$\square$ Series 1, Argentina, 12

Series 1, Dominican Republic, 12

$\square$ Series 1, Latin America, 21

Source: Latinobarómetro Corporation, Informe Latinobarómetro 2010, Santiago, Chile [online] http://www.latinobarometro.org/latino/ LATDatos.jsp.

The media are a source of power, institutions and firms that construct meanings and public imaginaries about conflict, socializing individuals. Just as the media need conflicts, conflicts need the media, which are public spaces where power relations are reflected, created and fought over and where conflicts between contending actors are recognized. The media are not neutral, but nor are they mechanical instruments of power; they are where political and social interests are expressed and where different journalistic approaches meet. They are also businesses. Their characteristics will depend on the market and on the interplay of interests and pressures among actors.

The concentration of media ownership is reflected in the types of Latin American media conglomerates. Three types or sizes of media conglomerates have been found to coexist in the region. The first, which may be termed "large", own businesses covering the four key communications platforms of the global market (print media, audiovisual media, web platforms and mobile multimedia) to differing degrees at the regional level; the term can also apply to those that do not have a presence in all four segments but own a large section of the media considered locally important in one or another of them. The second group or category, termed "medium-sized", are corporations which do not own media outlets outside their own country but operate in three or four of the communication platforms mentioned in their local market. Lastly, there is the "small" group, consisting mainly of publishers that have an ever-increasing ability to offer products on different platforms for different audiences but own no more than a couple of print publications, do not have complex distribution platforms and do not participate in major information and communication networks at the regional or global level. Table 1 exemplifies the features of the groups mentioned.

In the media/society dialectic, it is not only that there is a complementary relationship between the media and those involved in conflict. From a constructivist perspective, the media construct reality, helping to delineate narratives and imaginaries that ultimately have repercussions in the real world, i.e., in the political system, the decision-making process and the agencies of social actors. 
TABLE 1

Types of media conglomerate

"Large" media group

Publication

El País (Uruguay)

O Globo (Brazil)

El Mercurio (Chile)

La Tercera (Chile)

Reforma (Mexico)

La Prensa (Argentina)
Multimedia group

Grupo de Diarios América (GDA)

Organizações Globo/Grupo de Diarios América (GDA)

Grupo de Diarios América (GDA)

Grupo Copesa S.A./Consorcio Periodístico de Chile

Grupo Reforma

Multimedios La Capital

"Medium-sized" media group

Publication

El Tiempo (Colombia)

El Comercio (Peru)

El Periódico (Guatemala)

El Universal (Mexico)

El Panamá América (Panama)

El Nacional (Dominican Republic)

El Colombiano (Colombia)

Ultimas Noticias (Venezuela)

La Nación (Costa Rica)

La Prensa Gráfica (El Salvador)

Diario Libre (Dominican Republic)

La Nación (Paraguay)

La República (Uruguay)

El Espectador (Colombia)

La Prensa (Honduras)

La Jornada (Mexico)

El Día (Dominican Republic)

Jornal de Brasilia (Brazil)

$O$ Estado de São Paulo (Brazil)

El Deber (Plurinational State of Bolivia)

Los Tiempos (Plurinational State of Bolivia)

La Razón (Plurinational State of Bolivia)

El Heraldo (Honduras)

La Nación (Argentina)
Multimedia group

Grupo Planeta

Grupo de Diarios América (GDA)

Media Development Loan Fund (MDLF)

Grupo de Diarios América (GDA)

Grupo Epasa

Grupo Corripio

Periódicos Asociados Latinoamericanos

Cadena Capriles

Grupo de Diarios América (GDA)

Grupo Dutriz

Omnimedia Grupo Multimedia/Periódicos asociados latinoamericanos

Grupo Nación de Comunicaciones

Grupo ICK

Grupo Bavaria

Grupo Organización Publicitaria Sociedad Anónima (OPSA)

-

Grupo Corripio

Grupo Jornal de Brasilia

Grupo Estado

Grupo Líder

Grupo Líder

Grupo Líder

Grupo Organización Publicitaria S.A. (OPSA)

La Nación S.A.

"Small" media group

Publication

$A B C$ Color (Paraguay)

El Universo (Ecuador)

El Universal (Bolivarian Republic of Venezuela)

El Diario de Hoy (El Salvador)

La Tribuna (Honduras)

El Mercurio (Ecuador)

Diario Expreso (Peru)

Prensa Libre (Guatemala)

La Nación (Chile)

Correo (Peru)

Crónica (Paraguay)

Expreso (Ecuador)

La República (Costa Rica)

El Mundo (El Salvador)

La Hora (Guatemala)

La Prensa (Panama)

Página 12 (Argentina)

Jornal do Brasil (Brazil)
Multimedia group

Editorial Azeta S.A.

Grupo El Universo

Periódicos Asociados Latinoamericanos

América Interactiva

Carlos Roberto Flores Facussé

Grupo Merchán

Expreso S.A.

Casa Editorial Prensa Libre S.A.

Empresa Periodística La Nación S.A./Chilean State

Empresa Periodística Nacional S.A. (EPENSA)

Grupo Nacional de Comunicaciones

Grupo Gráficos Nacionales S.A. (Granasa)

República Media Group (RMG)

Grupo Mundo Multimedia

Familia Marroquín

Corporación La Prensa S.A. (Corprensa)

Editorial La Página S.A.

Nelson Tanure/Editora Jornal do Brasil

Source: Political Analysis and Prospective Scenarios Project-United Nations Development Programme (PAPEP-UNDP), Los conflictos sociales en América Latina, La Paz, 2011. 


\section{Thesis 3}

Conflicts have complex rationalities and differing intensities. Their frequency is not the same as their radicalism, and both are unequally related to levels of institutional legitimacy and social divides. Thus, the greater the social divides and the lower the level of institutional legitimacy, the more conflicts there are. Likewise, the more support there is for the institutional political regime, the fewer the conflicts that reach the point of violent clashes.

One of the patterns of social conflict in the region encountered by the present study was the asynchrony of conflict, i.e., there are conflicts with differing directions, intensities and meanings relating to basic living standards with demands (mainly directed at the State) for effective and legitimate institutional management and strategies for change in the dynamics of intercultural relations. At the same time, one of the central findings of the study is how complex the asynchrony of conflict is, since, as already mentioned, the deeper the divides in society and the weaker the legitimacy of the institutional regime, the greater the number of conflicts (see figure 4).

Again, the relationship between the radicalism of conflicts, institutional legitimacy, social divides and the number of conflicts is very important, but more complex. As noted earlier, the level of support for the institutional regime will determine whether or not conflicts reach the stage of violent clashes (see figure 5).

The relationship between social divides and radicalization is not linear but U-shaped: countries with intermediate divides have fewer cases of violence and

FIGURE 4



Source: Political Analysis and Prospective Scenarios Project-United Nations Development Programme (PAPEP-UNDP), Los conflictos sociales en América Latina, La Paz, 2011.

a There is no significant or major correlation between levels of institutional legitimacy and conflict radicalization; a reading of the chart indicates that there is no obvious relationship between legitimacy and conflict intensity in the region. On the other hand, there does seem to be a relationship between the number of conflicts and the level of institutional legitimacy: countries with lower levels of institutional legitimacy would appear to have a greater propensity to social conflict, although this relationship is not conclusive and is only marginally significant in statistical terms.

b LAPOP 2010: Latin American Public Opinion Project for 2010. 




Source: Political Analysis and Prospective Scenarios Project-United Nations Development Programme (PAPEP-UNDP), Los conflictos sociales en América Latina, La Paz, 2011.

clashes than countries with wide divides and countries with narrow divides. This appears to be due to the different forms of interaction between society, the State and conflicts, the ability to process these and, in general, a country's history and political culture. There is some good news here for the region, since there is now an "empty box" favourable to democracy and development: social conflict in the Latin American countries is neither very intense nor highly radicalized.

\section{Thesis 4}

The State is a central actor in the interplay of power and conflict, but it has only a limited capacity to manage them and resolve them in a way that contributes to social cohesion and extends democracy. The result is a paradox, with States catalysing social demands but lacking the capacity to manage them.

On the one hand, as figure 6 reveals, the main target of demands in Latin America is the State, accounting for $70 \%$ of cases. In other words, the State is the focus for social discontent in efforts to get demands met or attain objectives. On the other hand, society is undergoing a progressive fragmentation of collective actors and their identities, something that is reflected in a tendency for demands to proliferate outside of the traditional institutionalized frameworks of conflicts. 
FIGURE 6

\section{Actors targeted by and instigating demands ${ }^{a}$}
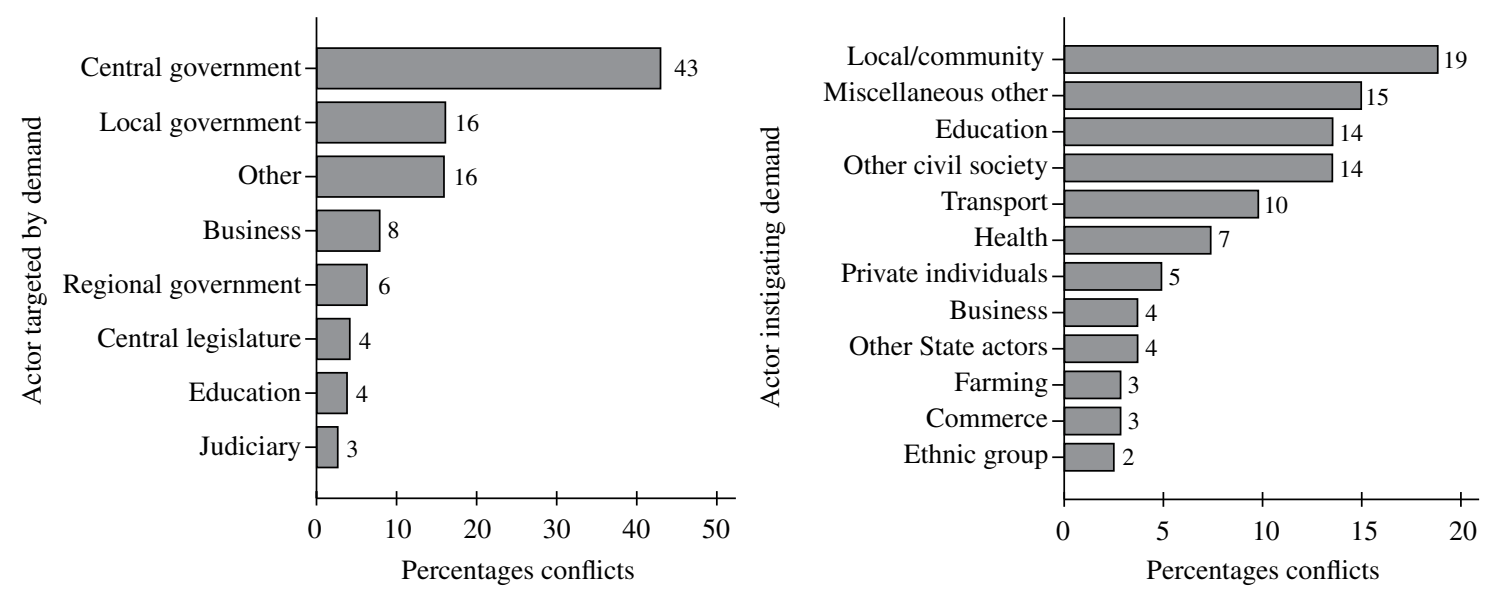

Source: Political Analysis and Prospective Scenarios Project-United Nations Development Programme (PAPEP-UNDP), Los conflictos sociales en América Latina, La Paz, 2011.

a The main actors in conflicts are local/community actors (19\%) and miscellaneous other (15\%), including circumstantial actors, irregular groups and groups associated with sectoral production and collective activities such as hydrocarbons, finance, mining, coordinating committees, unions, associations, trade bodies and education (14\%).

\section{III}

\section{Fragmentation}

A contrasting tendency can be seen among actors instigating demands in the region: the prevailing fragmentation of those engaging in conflict. The most important actors are local organizations (19\%), and it is also significant that $5 \%$ of conflicts are driven by circumstantial actors,${ }^{6}$ i.e., groupings of individuals

${ }^{6}$ These are collective actors who appear at the time of the conflict and then vanish. who are fighting for specific one-off demands and needs and whose organization breaks up once these concrete issues have been resolved. It is in this sector that the trend towards spontaneous collective action is most in evidence, embodying in terms of conflict that "liquid modernity" spoken of by Bauman (1999 and 2005). All this suggests the hypothesis that the prevailing situation is one of institutionally weak States and polycentric societies. 


\section{IV}

\section{Centrality}

For all the centrality of demands targeting States, situations vary greatly. There are countries with a greater State capacity (Uruguay) and thus a greater capacity for processing conflicts, and countries with lesser capabilities, such as the Plurinational State of Bolivia, Peru and Ecuador.

From a general perspective, the State is perceived almost everywhere in the region as the only actor capable of solving macrostructural problems and their local manifestations. There is a tendency towards centralization of social demands which confirms a historical pattern in the region whereby the State has played and continues to play a leading role. Conflicts are not distributed in a balanced way across the different social spaces, and demands most commonly take on a political connotation. As already pointed out by Calderón and Dos Santos (1987, p. 15), in Latin America "the lack of constitutional technologies capable of institutionalizing conflict management" compounds "the socially exclusive tendencies of order".

This leaves the paradox of a weak State as the main focal point for powerful social demands: appeals are still to a State machinery that is usually inadequate and unable to provide negotiated institutional responses, being trapped by the inefficiencies of its bureaucracy, the ineffectiveness of its legal system, the lack of credibility of its governments and chronic problems of corruption and patronage. At the same time, the process of centralization in the collective imaginary reaches the highest levels, where the central government is the State, indeed the president is the State, in a historical and cultural evolution where personality-driven rule has almost never ceased to play a central role in Latin American politics.

Lastly, it is necessary to stress the importance of the normative and institutional framework when it comes to understanding the dynamics of social conflict. This can play a very important role in channelling tensions and keeping potential outbreaks of violence under control, organizing social demands, providing actors with forums for recognition and expression and promoting dialogue-based political forms of decision-making. What is considered here is the value of democracy as a system that sets political ground rules capable of processing conflicts (Lechner, 1986). This being so, there seems to be no substitute for the institutional dimension when it comes to social change, and nor can demands for social citizenship or participation in decision-making be lastingly satisfied unless institutional limitations have been overcome (Calderón and Dos Santos, 1987, p. 17). Furthermore, manifest and deep-rooted dysfunctions in institutional systems lie at the root of specific cruxes of conflict, while at the same time they complicate the handling of social tensions of different kinds (both tensions over social reproduction and those relating to culture and political ideology).

\section{Thesis 5}

There is a tendency for conflicts to become decentralized and for local experiences with democratic conflict processing to emerge. This tendency leads to the development of a new politics centring on constructive relationships between actors and municipal measures that are characterized by legitimacy and effectiveness, possess civic agency in processes and results and ultimately construct a citizenship democracy on a local scale.

Despite the prevailing logic of centralism, or decentralization without deconcentration of resources, there are current and historical tendencies for conflicts to be decentralized down to the territorial, municipal or regional level of the State. As figure 6 illustrates, 16\% of all conflicts recorded in the study period involved demands directed at the local State and $6 \%$ demands directed at regional governments.

In some important cases, this trend has been associated with the emergence of sociocultural and political actors seeking to extend a constructivist policy. As can be seen from table 2, the cases of the cities of Porto Alegre, Rosario, Bogotá, La Paz and Villa El Salvador, among others, are remarkable examples of public policies being applied to the processing of social conflicts in favour of a pluralistic and substantive democracy better able to cope with the problems of inequality and development.

These experiences and others like them show that it is possible to find and perhaps disseminate examples where the attempt has been made to turn conflicts, or some part of them, into agreements that are transformed into goals and concrete results. 
TABLE 2

Paradigmatic decentralization processes in Latin America

\begin{tabular}{lll}
\hline Country & City & Process \\
\hline Brazil & Porto Alegre & Decentralization and local democratization \\
Bolivia (Plu. St. of) & La Paz & Decentralization and popular participation \\
Argentina & Rosario & Decentralization and local democratization \\
Uruguay & Montevideo & Participatory decentralization \\
Peru & Villa El Salvador & Participatory Development Planning and Budgeting System \\
Colombia & Bogotá & Administrative decentralization \\
\hline
\end{tabular}

Source: Political Analysis and Prospective Scenarios Project-United Nations Development Programme (PAPEP-UNDP), Los conflictos sociales en América Latina, La Paz, 2011.

\section{Thesis 6}

In a combined but unequal logic, there are three fields of conflict associated with social reproduction, institutional logic and the cultural dynamic. Social reproduction is organized by a practical logic and is an end in itself, as it constitutes an ethical touchstone for politics and culture: human dignity.

With the idea of obtaining a regional overview of collective action orientations, the study identifies three major fields of conflict in Latin America, encompassing the different demands that give rise to collective action: (i) social reproduction demands, (ii) institutional demands and (iii) cultural demands. The three fields partially differ in their rationale: (1) social reproduction conflicts mainly include demands for the satisfaction of the basic social welfare needs that are the minimum for a decent life, making possible the reproduction of individuals and human groups, and their logic is essentially practical; (2) institutional conflicts pursue greater effectiveness and legitimacy for State institutions; (3) the goal of cultural conflicts is to change the way people live (and they are thus strategic conflicts, as will be seen).

Figure 7 shows the percentage of each field of conflict by country and by subregion. It can be seen that social reproduction conflicts are the most numerous in the great majority of the countries, the exceptions being Colombia, the Dominican Republic, Guatemala, Panama and the Plurinational State of Bolivia, where institutional conflicts outweigh them. Colombia and Mexico are the countries with the greatest number of cultural conflicts.

Social reproduction means the ability of a society to reproduce itself and change over time, and concerns both basic reproduction thresholds (food, health, education, employment, etc.) and extended thresholds relating to quality of life in general and to the concepts of wellbeing and a decent life as a condition for true freedom
(Sen, 1999). It is in this field of conflict that the practical logic of social mobilization is becoming plainer to see. People take to the streets to ask for improvements in their living conditions and demand certain guarantees in the reproduction process, whether for better pay and employment conditions or assistance with health and education issues, or against economic measures that are perceived as destabilizing to the status quo.

Most social reproduction conflicts arise over socioeconomic issues, especially those involving employment and wages and collective consumption, but also as a rejection of certain political or social measures perceived as threatening the labour market status quo, and in support of norms that could improve the current situation, or over matters relating to land ownership and usage (see figure 8). Over half of all social reproduction conflicts are rooted in employment/wage demands $(59.20 \%)$. The relative importance of labour conflicts, in particular, reveals the strategic role work plays in the lives of our societies, in terms of both participation in employment and the quality of social life.

Furthermore, the data on social reproduction conflicts back up the structural data, in the sense that collective action seems to be consistent with the real socioeconomic problems perceived in the region. Social reproduction conflicts represent $47.3 \%$ of all conflicts in Latin America, and their relative importance is greater still if it is considered that these conflicts are the most numerous in 12 of the region's 17 countries, while in nine of them employment/pay issues and the economic situation are at the root of over $50 \%$ of conflicts.

At the subregional level, the Andean countries and Central America have similar levels of conflict over social reproduction, which accounts for some $42 \%$ of all conflicts in these areas, while the number of conflicts in the Southern Cone is larger (58.7\%) (see figure 9). 
FIGURE 7

Fields of conflict, by subregion and country (Percentages)

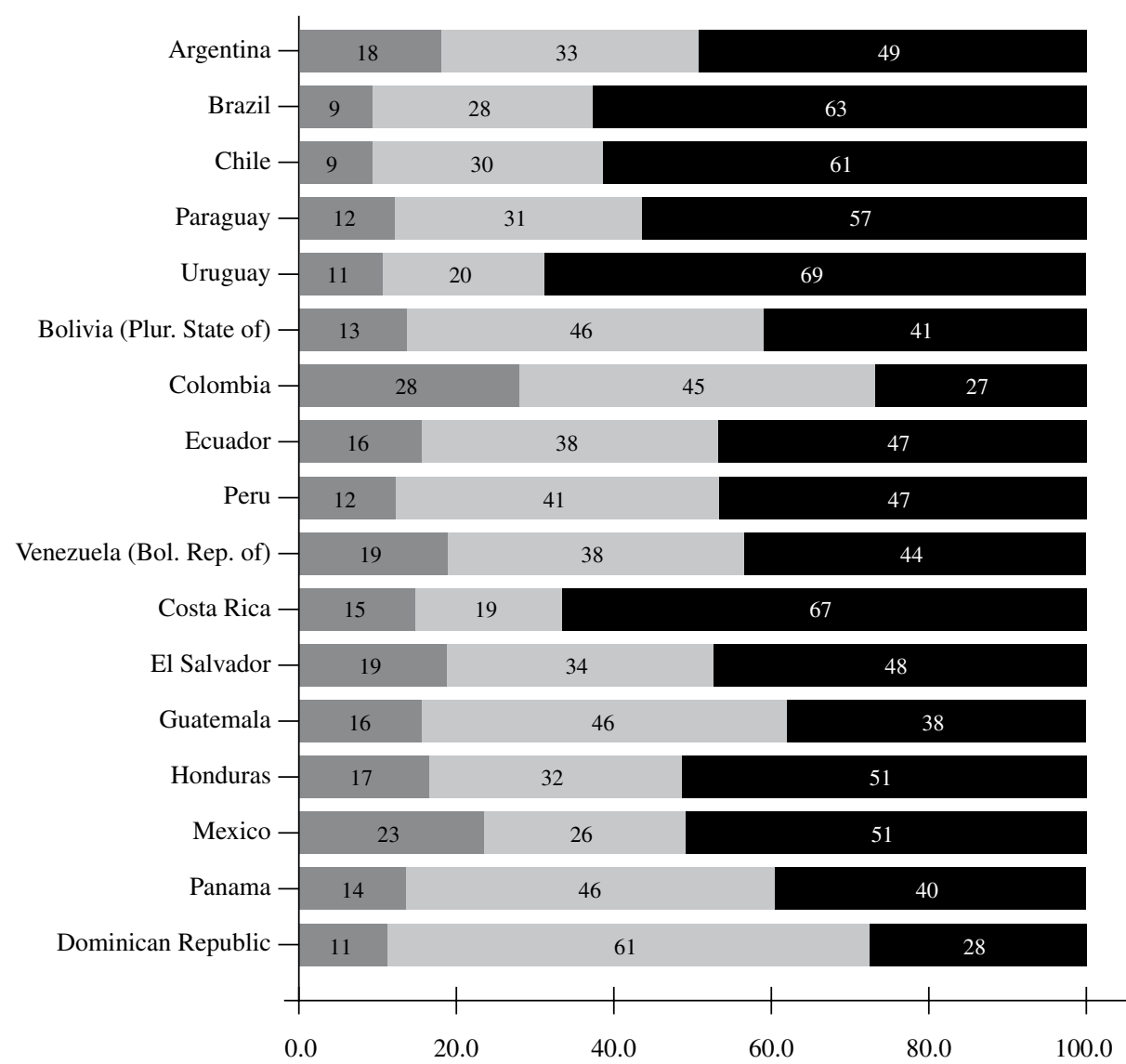

Field of conflict

Social reproduction

Institutions and management

Cultural

Source: Political Analysis and Prospective Scenarios Project-United Nations Development Programme (PAPEP-UNDP), Los conflictos sociales en América Latina, La Paz, 2011.

FIGURE 8

\section{Typology of conflicts}

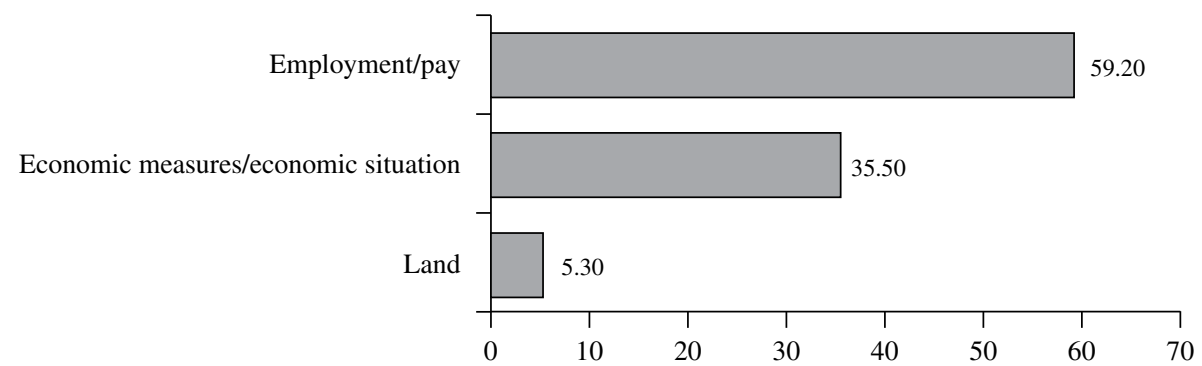

Source: Political Analysis and Prospective Scenarios Project-United Nations Development Programme (PAPEP-UNDP), Los conflictos sociales en América Latina, La Paz, 2011. 
In this field, conflicts that tend to acquire a significant level of radicalization are those relating to land (53\%) and employment/pay (49\%), and protests against economic measures $(42 \%)$ (see figure 10$)$.

The data on averages confirm that the most radicalized conflicts are those over land. Although there are fewer such conflicts, they present a greater tendency to violence than do other types. This suggests that, first, there is a lack of institutional spaces for dealing with these demands and, second, these conflicts tend to combine with other factors, such as the issue of identities in the case of ethnic groups, or local economic and political interests, which increases their centrifugal ideological charge. Furthermore, the agrarian question is still a pending issue on the reform agenda of many Latin American countries, and the social consequences of a "neo-feudal" latifundista system with strong roots in the region continue to make themselves felt.

\section{Thesis 7}

Institutional conflicts arise from dissatisfaction with the effectiveness and efficiency of institutions. A feature seen across the region is the strength of a "para-institutional" cultural of conflict.

Institutional conflict is a result of the inconsistency between people's demands and the inability of State policies and institutions to meet these.
FIGURE 9

Social reproduction conflicts

(Percentages)



Share of conflicts by country



Source: Political Analysis and Prospective Scenarios Project-United Nations Development Programme (PAPEP-UNDP), Los conflictos sociales en América Latina, La Paz, 2011.

FIGURE 10

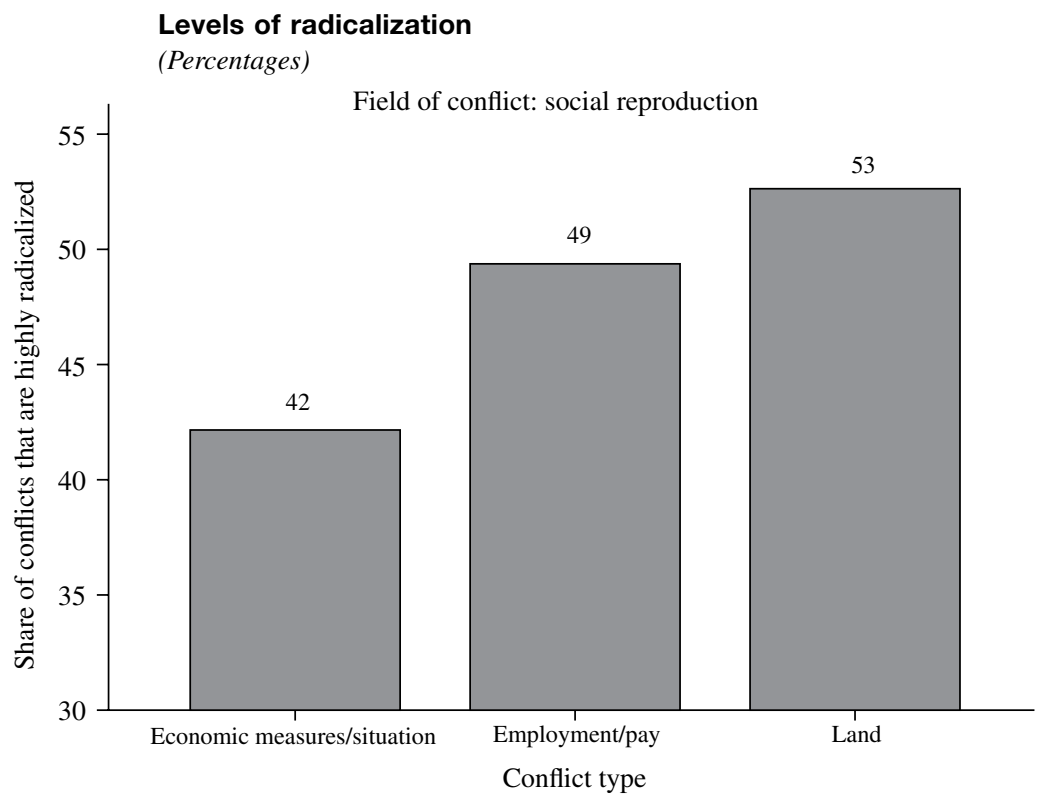

Source: Political Analysis and Prospective Scenarios Project-United Nations Development Programme (PAPEP-UNDP), Los conflictos sociales en América Latina, La Paz, 2011. 
In particular, there is an emerging type of conflict that is more focused on criticizing the functioning of institutions or the State than the system as such, although in some cases criticism of the system is a general background to the positions taken.

The rationale for conflicts in this category is the need to improve institutions, understood in their more practical aspects as administrative management, public service provision, legal and judicial problems and the legitimacy of the public authorities. Struggles arise over both the lack of institutional structures and demands for the institutionalization of social actors.

Many of the conflicts characterizing Latin America derive from the weak application of norms and the inefficiencies of the State rather than from a lack of norms and institutions. In this way, the State is a major generator of conflict.

Institutional conflict is the second most important area in quantitative terms, representing $37.7 \%$ of all conflicts, and includes demands motivated mainly by failings in administrative management (35\%) and the provision of public services $(30.2 \%$ ) (see figure 11 ). The former encompass demands motivated by observations or disagreements regarding the way institutional management is conducted, whether in the public or the private sphere, while the latter include any conflict caused by the lack of or shortcomings in public works (roads, schools, hospitals, etc.) in a particular area, and by inadequate State provision of basic services.

As regards the distribution of institutional conflicts in subregions, the Andean countries are where the most such conflicts are to be found $(41.2 \%$ of the total), especially Colombia and the Plurinational State of Bolivia. Institutional issues account for $41 \%$ of all conflicts in Central America, the Dominican Republic and Mexico. Two groups of countries stand out in this subregion: on the one hand, Panama, Guatemala and the Dominican Republic, where institutional conflicts are the most important class; and on the other, Honduras, El Salvador, Mexico and Costa Rica, with medium/low levels of institutional conflict. Lastly, $28.7 \%$ of conflicts in the Southern Cone are institutional, with medium levels in most countries (the exception is Uruguay, where just $20 \%$ of conflicts are of this type) (see figure 12).

The conflicts that most often tend to become highly radicalized are those relating to problems with administrative boundaries (56\%), questioning or acknowledgement of authority (49\%), administrative management $(41 \%)$, breach of agreements $(53 \%)$, public service provision (40\%) and legal situation/measures (28\%) (see figure 13). Radicalization is greater on average in the case of conflicts resulting from breaches of agreements and lower in the case of struggles relating to administrative boundaries and legal measures. The number of institutional conflicts and conflicts over issues of administrative management that become highly radicalized reveals the existence of structural causes that are at the base of the chronic weakness of institutional and governance mechanisms.

Latin America is characterized by the importance of a "para-institutional" dimension to conflict in many contexts. There is a grammar of relationships between

FIGURE 11

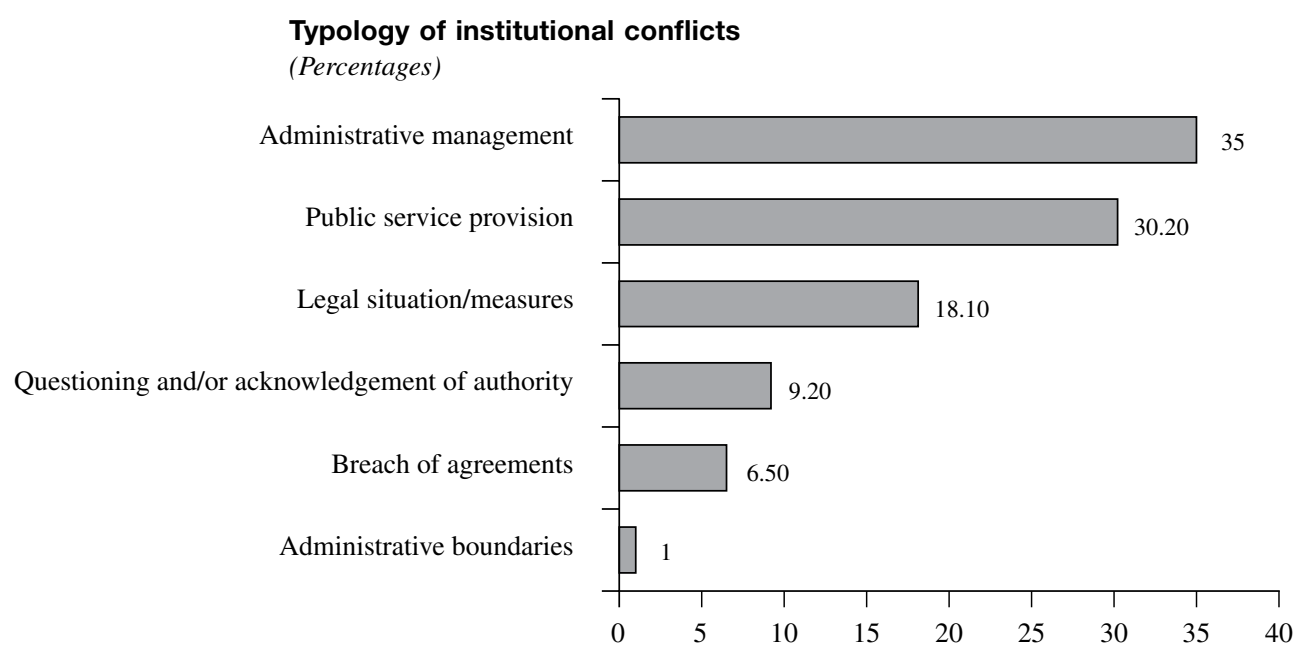

Source: Political Analysis and Prospective Scenarios Project-United Nations Development Programme (PAPEP-UNDP), Los conflictos sociales en América Latina, La Paz, 2011. 
FIGURE 12

\section{Institutional conflicts \\ (Percentages)}



Share of conflicts by country

Low 0 - 20

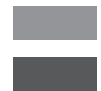

Medium 21 - 44

High 45 - 65

No information

Source: Political Analysis and Prospective Scenarios Project-United Nations Development Programme (PAPEP-UNDP), Los conflictos sociales en América Latina, La Paz, 2011. the State and social groups that shifts between the formal and the informal. These are syncretic systems that retain "pre-capitalist" and "pre-democratic" organizational and cultural features, combined with modern institutions. Thus, personal networks and informal hierarchies, embodied in systems of patronage and favouritism, operate as everyday mechanisms for regulating social relations between individuals and with formal institutions. It is precisely in this "para-institutional" sphere that social actors in conflict operate. ${ }^{7}$

Lastly, irrespective of political orientation and with some case-by-case variations, Latin America has a structural problem with the processing of conflicts, which has tended to worsen because of the political inability of institutions and the State to deal with demands and identify the needs and issues of most urgent concern to the population. The type of governance that results tends to be weak and unstable.

\footnotetext{
${ }^{7}$ Donzelot defines the Brazilian "art of negotiation" as a particular way of resolving conflicts through informal arbitration and negotiating mechanisms, in a practice that combines loose interpretation of legal principles, mutually agreed transgression of norms and the production of an informal legality with its own localized jurisdiction, free of the juridical and bureaucratic encumbrances of the State, all of which dislocates and subverts the supposed centrality and uniqueness of formal law as the organizing rule of life in society (Donzelot, 1994).
}



Source: Political Analysis and Prospective Scenarios Project-United Nations Development Programme (PAPEP-UNDP), Los conflictos sociales en América Latina, La Paz, 2011. 


\section{Thesis 8}

Cultural conflicts are undertaken in pursuit of new forms of social accommodation and have systemic and global effects, but are more fragmented than other types of social conflict. They are largely strategic conflicts.

As we have seen, the Latin America region has chronic institutional weaknesses and exceptionally high levels of socioeconomic inequality, and is consequently fertile ground for the reproduction of what are likewise strong mechanisms of cultural inequality.

It is upon this fabric of complex inequality that the new needs and demands on the multifaceted cultural mobilization agenda of Latin America are coming together, with ideological and political conflicts and those relating to citizen security at the forefront.

Although cultural conflicts in all their variants are less numerous than conflicts in other fields, they have very strong systemic repercussions, owing to the role culture is playing in the new globalized context of Latin America. In terms of their impact on globalization, governance and democracy, then, these are strategic conflicts.

This field includes those conflicts whose roots lie in culture on a broad definition, with a strong accent on everyday life, subjectivities and multiple identities, and the culture industry and market. These conflicts are relatively few in number by comparison with the other fields (they represent $15 \%$ of all conflicts); however, they are a crucial category for understanding today's social dynamics and the grammar of conflict in its new manifestations.

Cultural demands are usually about recognizing or strengthening the identities of individuals and actors and attaining a certain quality of life, focusing in the abstract on third generation rights and the concept of cultural citizenship. These conflicts express the need to affirm a type of socialization, both subjective and collectivist, in which social relationships and acceptable conditions of security are redefined.

Citizen security demands generate just over $28 \%$ of cultural conflicts. These are usually protests about a lack of protection against crime. The second most common type of demands are those relating to struggles over political ideology (about $25.7 \%$, totalling 89 conflicts). These are struggles between factions (usually political parties, internal groups within them or the like) over opposing ideological visions that have taken on a confrontational character. Some $24 \%$ of cultural conflicts are triggered by problems with natural resource use and deteriorating environmental quality as a result of specific actions taken by public or private agencies, or both (see figure 14). These demands may be conducted more within environmentalist parameters or from an instrumental perspective of control over natural resources, as the case may be. The success of these movements could be due in part to their ability to tie in the particular with the universal, stressing the current development pattern and some globalized values that are hard to question, such as protection of the global ecosystem.

FIGURE 14

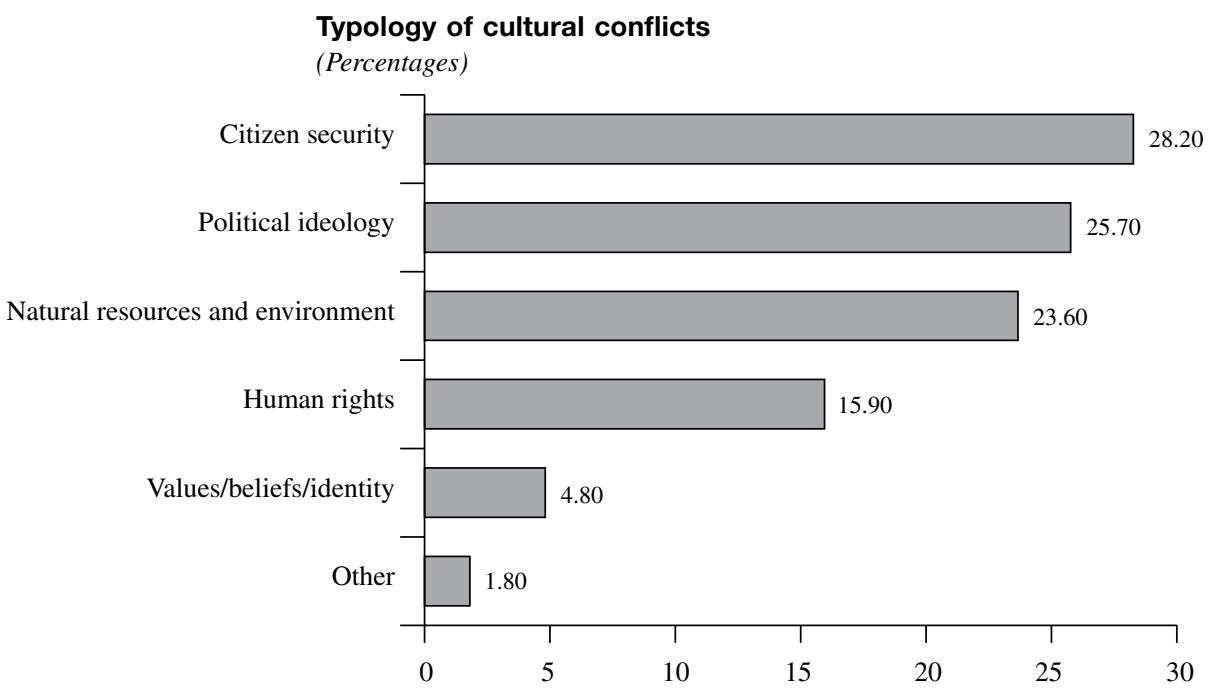

Source: Political Analysis and Prospective Scenarios Project-United Nations Development Programme (PAPEP-UNDP), Los conflictos sociales en América Latina, La Paz, 2011. 
At the subregional level, cultural conflicts are $16.3 \%$ of the total in the Central America, Dominican Republic and Mexico subregion, $15.5 \%$ in the Andean countries and $12.6 \%$ in the Southern Cone. Some of the countries with the most conflicts are to be found in the northern Andes: the Bolivarian Republic of Venezuela and Colombia. The pattern in the Southern Cone is generally around the average, with two tendencies: Argentina on the one hand, with the largest number of cultural conflicts in absolute terms, and Brazil and Chile on the other. In Central and North America, lastly, El Salvador and Mexico stand out for their high levels of conflict, something that can be accounted for partly by their ethnic diversity, but most especially by the high levels of insecurity and human rights violations in those countries (see figure 15).

Conflicts over political ideology are the most likely to become radicalized in percentage terms (34\%), followed by those relating to citizen security (32\%), struggles over environmental issues (26\%), human rights disputes (20\%) and, lastly, those concerning values, beliefs and identities (13\%) (see figure 16). As regards the averages for radicalization of cultural conflicts, struggles over political ideology or citizen security tend to be the most violent. The figure for the other conflicts category is $17 \%$.

Generally speaking, political and ideological radicalization seems to be a factor that seriously affects governance and democratic coexistence, owing to the risk of degeneration into violent clashes and confrontation. Given this, it seems essential for agreements to be reached in pursuit of political and ideological accommodation in shared democratic spaces.

In the area of cultural conflicts, lastly, young people appear to play a fundamental role as subjects of mobilization and producers of new social demands. The tendency towards mobilization has also been heightened because of the extent to which young people's expectations have been frustrated, owing to the negative socioeconomic situation of the previous period, institutional mistrust and rapid incorporation into "information" culture. This frustration is one of the drivers of conflicts, together with a perception of insecurity and exclusion as factors intrinsic to daily life, the breakdown of imaginaries and strains between the collective and individual levels. The young are a crucial section of society, embodying great potential for change and new thinking, and at the same time a Pandora's box with the potential to cause chaos if their demands, expectations and frustrations are not successfully channelled. Thus, young people are like conflicts: potentially dangerous, but also renewers of the social order. Women are also crucial actors in
FIGURE 15

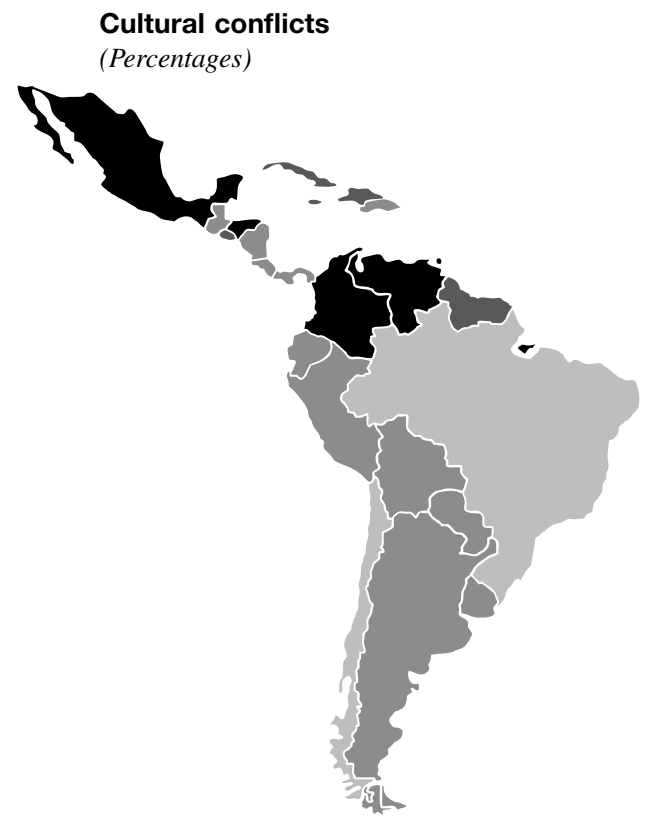

Share of conflicts by country

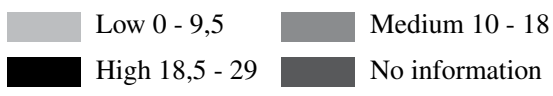

Source: Political Analysis and Prospective Scenarios Project-United Nations Development Programme (PAPEP-UNDP), Los conflictos sociales en América Latina, La Paz, 2011.

cultural conflicts. Although gender tensions receive little expression and recognition in the public media space, they do have potential for cultural and strategic change in modern societies, most particularly because of the new thinking women can bring to politics and society as promoters of change and justice.

\section{Thesis 9}

There is a growing tendency for traditional and new conflicts and actors to move on to information and communication networks.

The region is part of a new global system constituted by real-time networks of communication flows. These new forms of communication, knowledge and lifestyles that society has now incorporated have given rise to what Castells calls the "network society" (Castells, 1997).

The web has become the place where the new forms of conflict and power are expressed and developed. The culture of "technosociability" is changing not only the daily lives of individuals and communities, but politics as well. As for social conflicts, media politics plays an 




Source: Political Analysis and Prospective Scenarios Project-United Nations Development Programme (PAPEP-UNDP), Los conflictos sociales en América Latina, La Paz, 2011.

important role, as holding a protest or march without the presence of the media, whether vertical (television, radio and newspapers) or horizontal (the Internet and mobile phones) means that the demands expressed have little impact and are less likely to be met.

The new ways of communicating have led to intensive use of ICTs in the public space. This space is understood as the "meeting point" where ideas and values are shaped, transmitted, supported and combated (Castells, 2009). ICTs allows actors to interact more nimbly, flexibly and spontaneously and to participate more actively in politics. The ease of access and low usage costs of both the Internet and mobile phones increase the scope for collective action. ${ }^{8}$ Participating in a forum, a blog or a group within a social network is more easily achievable than other forms of political participation. Nonetheless, the information society reproduces the structural social

\footnotetext{
${ }^{8}$ Many of the region's countries doubled Internet usage in the period from 2002 to 2010 (Informe Latinobarómetro, 2010) and about $80 \%$ of Latin Americans own and use a mobile phone (International Telecommunications Union, ITU).
}

divides of Latin American society. And if the region's countries continue with an "informationalist" logic without making the switch to the model which characterizes the information society, the economic capacity to integrate the population into an inclusive development process will not be attained (Calderón, 2003).

As can be seen in figure 17, there is a direct relationship between the Human Development Index (HDI) and the percentage of Internet usage. According to the data, countries such as Argentina and Chile rank highest for both indicators, while Paraguay, Honduras and Guatemala are at the other extreme.

These data can be interpreted as showing the existence of a feedback loop between the two variables. In other words, access to ICTs and the Internet in particular could be seen as a factor that directly and indirectly benefits development indices, since they are tools that can improve people's levels of social and political information and participation, as well as their basic living conditions in terms of nutrition, health and education; although they can also be tools for domination. Accordingly, "technology is a tool for 
FIGURE 17 Human Development Index (hdi) and Internet usage (Index scores and percentages)



Source: Political Analysis and Prospective Scenarios Project-United Nations Development Programme (PAPEP-UNDP), Los conflictos sociales en América Latina, La Paz, 2011.

growth and development" (UNDP, 2001, pp. 29-30). Latin America is faced with a major challenge: narrowing the digital divide and participating fully in the growth model that is developing around the new technologies.
One important step towards this is to provide access to the new technology for the whole of society, especially the young, and structurally reform the education system so that ICTs are adopted there (Calderón, 2003).

\section{V}

\section{Actors on the web}

\section{(a) Traditional actors}

Many traditional sociocultural actors and movements in Latin America use web pages to position themselves within their countries or internationally. They use this medium to disseminate their values and ideas, thereby increasing their prospects of promoting political or cultural change and influencing opinion. Furthermore, using ICTs, and particularly the Internet, enables movements to interact and coordinate activities both internally and with other networks and organizations, thus socializing experiences.
Figure 18 shows that the development level and the percentage of Internet take-up both affect the number of actors with a presence on the web. On the one hand, countries such as Costa Rica, Argentina, Uruguay and Chile present high HDI scores and greater Internet usage, with a large percentage of actors represented on the web. At the other extreme are Paraguay, Guatemala and the Plurinational State of Bolivia, the region's least developed countries and those with the lowest Internet usage, where only a very small percentage of social actors have web pages, blogs or social networks to disseminate their demands. 
FIGURE 18

$$
\text { Proportion of leading actors with a web presence, by country }
$$

(Percentages)

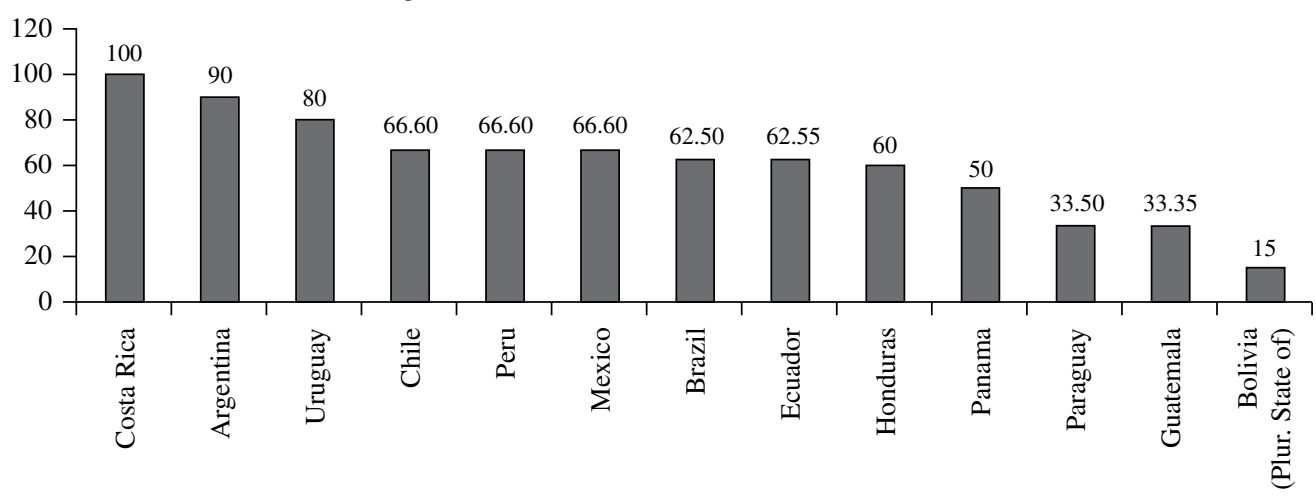

Source: Political Analysis and Prospective Scenarios Project-United Nations Development Programme (PAPEP-UNDP), Los conflictos sociales en América Latina, La Paz, 2011.

a Only actors with more than five conflict episodes in a particular conflict over the study period were considered.

\section{(b) Spontaneous actors ${ }^{9}$}

These emerge from the web, since whenever any widespread demand or discontent arises, it is transmitted spontaneously by thousands of people in a relatively short time through social networks, blogs, forums, chain e-mails or text messages. In the event of conflict, citizens can use these instruments to organize and spread information. De Ugarte (2010) calls this "cyberactivism", meaning a strategy for changing the public agenda by disseminating a particular message and encouraging its spread by word of mouth, which is multiplied by personal electronic communication and publishing techniques. There have been cases in recent years where the public agenda has been successfully changed in this way. Cyberactivism

\footnotetext{
${ }^{9}$ Examples of spontaneous actors in Latin America are: (i) the student protestors known as the "penguins" in Chile, (ii) the InternetNecesario movement on Twitter in Mexico and (iii) "Un millón de voces contra las FARC" ("A million voices against FARC") in Colombia. Case (i) occurred in 2006, with the demands of Chilean students for improved education quality. The success of the "penguin movement" was possible because of the way the students were organized, using ICTs to coordinate throughout the conflict. Case (ii) arose in 2009 on the Twitter social network in Mexico and reflected the discontent of thousands of users at the approval by the Chamber of Deputies of an increase of $3 \%$ in the cost of telecommunications from 2010. The reaction of users was immediate: "The Internet is not a luxury," they claimed on Twitter, the result being a cyberprotest that lasted from 10 p.m. on 19 October to 5 a.m. on 20 October. Case (iii) was an action that took place on the Facebook social network in January 2008 in Colombia, with the goal of organizing a massive countrywide march against violence. There were eventually 300,000 adherents (Neumayer and Raffl, 2008) and its repercussions extended beyond the social network to the media and the real-world public space.
}

has two phases: a deliberative phase, when blogs and forums are used to start the debate, and a mobilization phase, when e-mails and mobile text messages are used to get people out on to the streets.

One consequence of globalization has been the enhancement of individual capabilities, with spontaneity, determined political activism and self-organization coming to the fore (Beck and Beck-Gernsheim, 2002); as a result, it has become indispensable to redefine collective projects on the web. "The issue is the way individual action is the outcome of a collective commitment, and collective action can be viewed from the standpoint of individual agency" (UNDP, 2009).

\section{Thesis 10}

A constructivist policy creates or improves a democratic society and is a powerful resource for coping with conflicts and adverse social climates. National situations are diverse and are inseparable from the social climate being experienced and the country's political and institutional capacity for conflict processing.

The argument of this thesis is essentially hypothetical and prospective in character. It raises two questions. What conditions or what social climate affect the dynamic of conflicts? And is there the political and institutional capacity to process them?

By social climate is meant all the objective and subjective conditions in which conflicts arise, especially those connected with the equity, institutional structures and multiculturalism characterizing a particular country. 
By conflict processing capacity is meant the capacity to move towards an equilibrium characterized by a legitimate State with wide-ranging and effective institutional instruments and spaces for processing conflicts in a positive way, together with an active society characterized by strong citizen participation in public life and a dynamic of creative collective action.

In other words, the need is for societies with actors who do not just protest but interact with other actors and the State, projecting themselves as thoughtful, autonomous subjects of development and democracy.

In general terms, Latin American States deal with an average of 11 new conflicts a month, the countries where there are the most conflicts being the Plurinational State of Bolivia, Peru and Argentina, with over 200 in total. The countries with the fewest conflicts in the region are Costa Rica, Chile and El Salvador, with an average of 59 .

The data reveal the existence of a Latin American society with a significant capacity for social action, but also with major asymmetries in mobilization capabilities. While the Plurinational State of Bolivia stands at one extreme with an average of 21.8 new conflicts a month, Costa Rica is at the other with an average of 2.3 conflicts a month (the ratio between the two averages is 9 to 1 ). This is all without classifying specific social movements and struggles.

It is not only a society's capacity to mobilize or act collectively that has to be analysed, however. There is also the matter of the political and social capacity for processing conflicts when they do arise, whether numerous or not, and the set of collective imaginaries regarding conflict that are established in that society. Thus, a society and political environment capable of treating conflict as an opportunity to alter certain conditions rather than as something harmful or a hindrance to development will have a greater capacity to process conflict and to progress democratically. Similarly, a society that mobilizes but treats mobilization and conflict as an opportunity to seek and generate agreements (or the conditions for agreements) and not as a way of imposing a vision or an agenda is a society with conflict processing capacity.

Where society is concerned, then, the ability to process conflict is, first, the capacity it has for acting collectively, for mobilizing and protesting; and second, the ability to endow these processes with legitimacy through both the socialization of information and participation by the actors themselves in accordance with a constructivist logic. On the part of the State, the ability to process conflicts means both the capacity of institutions and parties for managing them and the way the State usually approaches them. Thus, there are States that are able to manage conflicts through the medium of solid institutions and States that use informal methods to manage conflicts.

Setting out from these variables, four dynamic scenarios were identified (see figure 19):

i. Countries where social tensions are generally low and the tendency is towards a constructive, pluralistic order of conflict (scenario 1).

ii. Countries that have a rigid or disproportionate institutional order and that tend to deal repressively with conflict or deny it (scenario 2).

iii. Countries which are highly vulnerable to upheavals and where the predisposition to deal constructively with conflict is severely limited (scenario 3 ).

iv. Countries which have an unstable order because their conflict processing capacity is weak and which have difficulty dealing with widespread social discontent (scenario 4).

These scenarios were used to construct a dynamic typology of the situation and prospects of the different countries, showing both countries with a considerable capacity for processing conflicts and a climate of social well-being (such as Costa Rica and Uruguay) and others with serious problems in their social climate and stark difficulties when it comes to processing conflicts (such as Honduras and Guatemala). In all cases, scenarios of

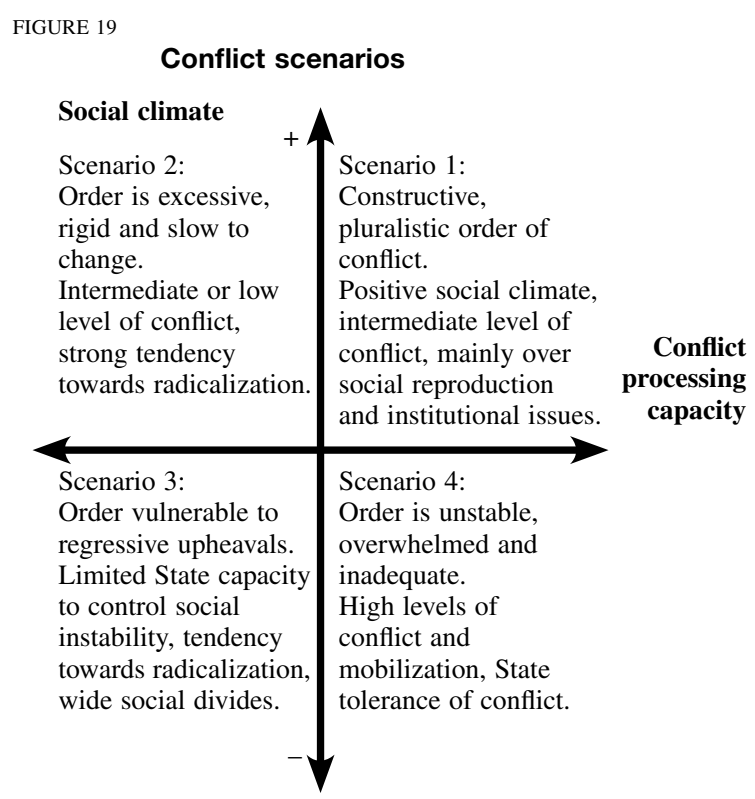

Source: Political Analysis and Prospective Scenarios Project-United Nations Development Programme (PAPEP-UNDP), Los conflictos sociales en América Latina, La Paz, 2011. 
improvement in the two variables at stake were identified. Figure 20 illustrates the situations and likely historical trajectories in the region.

To conclude and sum up, the countries of Latin America share common features where conflict is concerned: platforms of exclusion and chronic inequalities that citizens mostly question, complex conflicts that relate these inequalities to the number of conflicts and their intensity, a combination of social protests manifested both at the social and national level and on the cultural/ global level, practical rationalities in conflicts over social reproduction, side by side with demands for greater institutional effectiveness and efficiency and cultural conflicts of a systemic character. Other features include States that are omnipresent in all spheres of conflict, but with severe limitations when it comes to processing them, and societies whose conflicts are increasingly fragmented, new public spaces associated with communication systems where conflicts are represented in contradictory ways, and conflicts that are tending increasingly to move on to information and communication networks with multiplier effects in the new environments of power. In short, there is increased social complexity associated with political systems and States whose ability to manage it is limited. The situations and scenarios in prospect are diverse and options remain open.

FIGURE 20

\section{Regional trends}

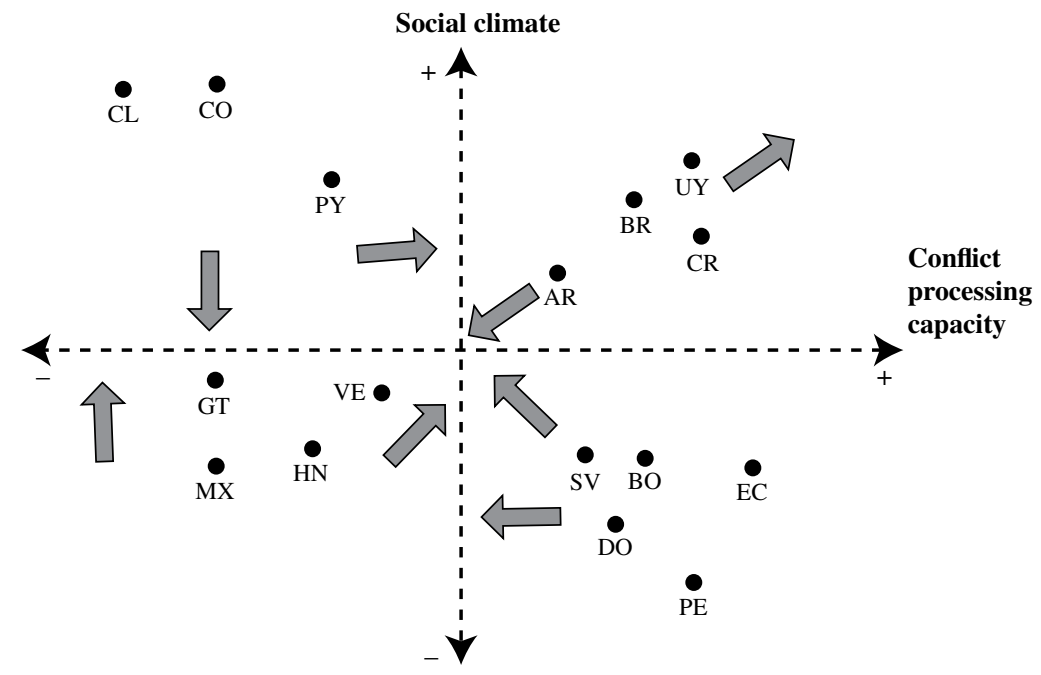

Source: Political Analysis and Prospective Scenarios Project-United Nations Development Programme (PAPEP-UNDP), Los conflictos sociales en América Latina, La Paz, 2011.

(Original: Spanish)

\section{Bibliography}

Ansaldi, W. (comp.) (1986), La ética de la democracia. Los derechos humanos como límite frente a la arbitrariedad, Buenos Aires, Latin American Social Sciences Council (CLACSO).

Aranibar, A., F. Vázquez and J.C. Garzón (2011), Los caminos diferenciados de la democracia en América Latina. Lecciones aprendidas de la gestión política de la crisis económica internacional, La Paz, Organization for American States/United Nations Development Programme.

Bauman, Z. (2005), Identidad, Madrid, Losada.

(1999), Modernidad líquida, Buenos Aires, Fondo de Cultura Económica.

Beck, U. and E. Beck-Gernsheim (2002), La individualización: El individualismo institucionalizado y sus consecuencias sociales y políticas, Barcelona, Paidós.

Boudon, Raymond and François Bourricaud (1982), Dictionnaire critique de la sociologie, Paris, PUF.

Calderón, F. (2008), "A historic turning point. Political change and the socio-institutional situation in Latin America", cepal Review, No. 96 (LC/G.2396-P), Santiago, Chile.
(2003), ¿Es sostenible la globalización en América Latina? Debates con Manuel Castells, Santiago, Chile, Fondo de Cultura Económica.

(1986), Los movimientos sociales ante la crisis, Buenos Aires, United Nations University (UNU)/Latin American Social Sciences Council (CLACSO)/Institute of Social Research of the National Autonomous University of Mexico.

Calderón, F. and M. Dos Santos (comps.) (1987), Los conflictos por la constitución de un nuevo orden, Santiago, Chile, Latin American Institute for Transnacional Studies (ILET).

Castells, M. (2009), Poder y comunicación, Madrid, Alianza.

(1997), "Economía, sociedad y cultura", La era de la información, vol. 1, Madrid, Alianza.

De Ugarte, D. (2010), "El ciberactivismo, la nueva revolución de la militancia política. Internet y los celulares son sus armas", La nación [online] http://www.lanación.com.ar/nota. asp?nota id=1049795.

Donzelot, J. (1994), L'invention du social: essai sur le declin des passions politiques, Paris, Seuil. 
ECLAC (Economic Commission for Latin America and the Caribbean) (2010a), Time for equality: closing gaps, opening trails (LC/G.2432(SES.33/3)), Santiago, Chile.

(2010b), Latin America in the Mirror: Objective and Subjective Dimensions of Social Inequity and Well-being in the Region (LC/G.2419), Santiago, Chile.

(2010c), Social Panorama of Latin America 2010, Santiago, Chile.

(2009), CEPALSTAT [online] http://websie.eclac.cl/sisgen/ ConsultaIntegrada.asp.

Forbes (2011), "The world's most powerful people", New York.

ITU (International Telecommunication Union) (2009), "World Telecommunication Indicators Database", Geneva [online] http://www.itu.int/ITUD/icteye/Reporting/ShowReportFrame. aspx? ReportName $=/$ WTI/CellularSubscribers Pub lic \&ReportFormat $=$ HTML4.0\&RP_int Year $=2009 R_{\text {R }}$ intLanguageID $=1 \& R P$ _bitLiveData $=$ False.

Latinobarómetro Corporation (2010), Informe Latinobarómetro 2010, Santiago, Chile [online] http://www.latinobarometro.org/latino/ LATDatos.jsp.

Lechner, N. (1986), La conflictiva y nunca acabada construcción del orden deseado, Madrid, Centro de Investigaciones Sociológicas.

Neumayer, Ch. and C. Raffl (2008), "Facebook for protest? The value of social software for political activism in the anti
Farc rallies", Salzburg, University of Salzburg [online] http://www.digiactive.org/wp-content/uploads/research1_ neumayerra.pdf.

PAPEP-UNDP/Fundación UNIR Bolivia (Political Analysis and Prospective Scenarios Project-United Nations Development Programme) (2011), Los conflictos sociales en América Latina, La Paz.

Sen, A.K. (1999), Development as Freedom, New York, Knopf. Touraine, A. (1988), La parole et le sang, Paris, Odile Jacob. UNDP (United Nations Development Programme) (2010), Regional Human Development Report for Latin America and the Caribbean 2010. Acting on the Future: Breaking the Intergeneracional Transmission of Inequality, New York.

(2009), Informe sobre desarrollo humano para Mercosur 2009-2010, Buenos Aires, Libros del Zorzal.

(2004), La democracia en América Latina. Hacia una democracia de ciudadanos y ciudadanas, Buenos Aires, Alfaguara.

(2001), Human Development Report 2001. Making New Technologies Work for Human Development, New York.

Vattimo, G. (2006), "Conferencia en La Moneda", Santiago, Chile. Vega, J.E. (2004), "Diversidad, igualdad y exclusión, multiculturalismo y democracia: promesas y problemas", Multiculturalismo y democracia, F. Calderón, La Paz, United Nations Development Programme (UNDP). 